\title{
Regulation of the Immune System By Synthetic Polynucleotides
}

\author{
IV. Amplification of Proliferation of \\ Thymus-Influenced Lymphocytes ${ }^{1}$
}

\author{
Robert E. Cone ${ }^{2}$ and Arthur G. Johnson \\ Department of Microbiology, The University of Michigan, Ann Arbor 48104
}

Received June 30, 1971

\begin{abstract}
The role of thymus-influenced antigen reactive cells (ARC) in the immune response was studied with the aid of a potent adjuvant to both antibody formation and cell-mediated immunity, polyadenylic-polyuridylic acid complexes (poly $A: U$ ). The polynucleotide complex increased the anti-sheep erythrocyte rosette forming cell response of irradiated mice after thymus cells were exposed to poly $\mathrm{A}: \mathrm{U}$ in civo or in zitro prior to injection of bone marrow cells. This direct stimulatory action resulted in an enhancement of the rate of proliferation of $\mathrm{ARC}$ in response to antigen and a shortening of the interval between antigenic challenge and the initiation of division in immunocompetent cells. No stimulatory effect of poly $\mathrm{A}: \mathrm{C}$ on bone marrow derived antibody forming precursor cells was observed.

It is suggested that ARC play an important role in the regulation of the length of the induction period, as well as the rate of increase of antibody forming cells in response to some antigenic stimuli.
\end{abstract}

\section{INTRODUCTION}

Complexes of polyadenylic acid and polyuridylic acid (poly A:U) have been found to cnhance the immunc response to shcep red blood cells (SRBC) in lethally irradiated mice reconstituted with a constant number of bone marrow cells (B cells) and graded numbers of thymus cells ( $\mathrm{T}$ cells). The elevation in anti-SRBC rosette forming cells (RFC) was inversely proportional to the number of $\mathrm{T}$ cells injected. Conversely, poly $A: U$ was not able to enhance the immune response of irradiated mice when injected with graded numbers of $\mathrm{B}$ cells and a constant number of $\mathrm{T}$ cells (1). Although the data suggested that the adjuvant action of poly $A: \mathrm{C}(2,3)$ was mediated through an effect on $T$ cells rather than through the B cells, the evidence was indirect. Direct evidence in support of a stimulatory effect of poly $A: U$ on $T$ cells was obtained in experiments described herein by exposing $T$ cells alone to poly $\mathrm{A}: \mathrm{U}$ either in vivo or in vitro prior to the addition

1 Supported by United States Public Health Service Grant AM 14273.

2. F. G. Nory Research Fellow. Prescnt address: The Walter and Eliza IIall Institute of Medical Research, Melbourne 3050, Australia. 
of $B$ cells. The data revealed that one mode of action of this adjuvant was to increase the rate of proliferation of $T$ cells and decrease the time at which cell division could be initiated by antigen.

\section{MATERIALS AND METHODS}

Animals. BALB/Aj mice originally obtained from Dr. William H. Murphy, Jr., Department of Microbiology, The University of Michigan (4) were inbred in our laboratory. Mice were either 4-5 weeks or 9-10 weeks old when used.

Antigen. Sheep red blood cells were obtained from the Colorado Serum Company, Denver, Colorado. The cells were stored at $4^{\circ} \mathrm{C}$ in modified Alsever's solution, washed 3 times and resuspended in phosphate buffered saline (PBS), pH 7.2 for injection. In all jnstances mice received $4 \times 10^{s}$ SRBC intravenously.

Homoribopolynucleotides. Polyadenylic acid (poly A), potassium salt. (lot nos. 1.10748, 11-59-301) and polyuridylic acid (poly U), ammonium salt. (lot nos. 411454, 11-6-308) were purchased from Miles Laboratories, Elkhart. Indiana. Polymers were complexed in vitro to form poly $A: U$ by mixing equal anounts of the polynucleotides before use as described previously (3).

Coll Preparations. Single suspensions of $T$ cells, spleen cells or $B$ cells were prepared as described previously (1). Thymus lobes or spleens were minced in cold PBS, $\mathrm{pH} 7.2$, the cell st1spension passed through a \#80 gauge stainlcss sted mesh into PBS, washed $3 \times$ and resuspended in PBS, pH 7.2 to appropriate concentrations. Suspensions of bone marrow cells were prepared by flushing the marrow from femurs and tibias with a syringe and 26 gauge needle containing cold Eagle's basal medium. The extruded plugs were dispersed by aspiration with a 21 gauge needle and syringe, the cells washed $3 \times$ in cold PBS 7.2 and resuspended to an appropriate volume.

Thymectomy. Eighteen to $24 \mathrm{hr}$ old mice were thymectomized according to the method of Sjodin et al. (5) as described previously (1). Thymic lobes were removed by aspiration. Prior to removal of spleens for rosette analysis the mice were examined with the aid of a dissecting microscope for the presence of thymic remnants. Mice with thymic remnants were excluded from the study.

Irradiation. Balb mice, 9-10 weeks old received $800 \mathrm{R}$ whole-body irradiation at a distance of $100 \mathrm{~cm}$ from a colbalt 60 source delivering $67 \mathrm{R} / \mathrm{min}$.

Drugs. Vinblastine sulfate (Eli Lilly and Company) was obtained from The University of Michigan Hospital pharmacy. The drug was dissolved in $0.85 \mathrm{r}^{\prime}(\mathrm{v} / \mathrm{v})$ saline at a concentration of $1 \mathrm{mg} / \mathrm{ml}$ and stored without preservative at $4^{\circ} \mathrm{C}$.

In vitro incubation of thymus cells and bone marrow cells. $\mathrm{T}$ or $\mathrm{B}$ cells were suspended to lesignated concentrations in Eagle's basal medium (BME) containing $2 \mathrm{~mm}$ D-glutamine and appropriate concentrations of SRBC \pm poly $A: C$. Ten $\mathrm{ml}$ of the cell suspension were added to $50 \mathrm{ml}$ siliconized screw-capped Erletmmeyer flasks. A gas mixture of $95 \%$ air, $5 \% \mathrm{Co}_{2}$ was introduced into each flask and the suspensions were inculbated at $37^{\circ} \mathrm{C}$ on a shaking water bath for $90 \mathrm{~min}$. After incubation the cells were washed 4 times with 50-100 volumes of PBS, pH 7.2, resuspended in PBS, pH 7.2 and injected intravenously with antigen in $0.4 \mathrm{mll}$ volumes.

Rosette 1 ssay. Anti-SRBC antilody forming cells in the spleens of mice were 
entmerated by the rosette assay as described previously (1). Spleens from each experimental group were pooled, dispersed, and washed in PBS $\mathrm{pH} 7.2$. To $1 \mathrm{ml}$ of the washed, monodisperse spleen cell suspension was added $0.1 \mathrm{ml}$ of a $10 \%$ suspension of washed SRBC and this mixture was incubated for $1.5 \mathrm{hr}$ at $37^{\circ} \mathrm{C}$ and overnight at $4^{\circ} \mathrm{C}$. Rosette forming cells ( $\mathrm{RFC}$ ) were enumerated by counting the spleen cell-SRBC mixture in a hemocytometer at $200 \times$ magnification. Approximately 5,000 to 10,000 spleen cells were counted depending on individual experiments.

Criterion for determining positive and negative responding splecns. The criterion for designating whether or $110 \mathrm{t}$ an innume response was initiated in the spleens of irradiated mice receiving SRBC, excess $B$ cells and limiting numbers of $T$ cells was the appearance in the spleen of 10,000 or more $\mathrm{RFC}$. This was based on the fincling that negative control groups, composed of mice receiving only one of the two cell types plus antigen, had a mean of $4,200 \pm 1,300 \mathrm{rfc} / \mathrm{spleen}$, representing pooled data from a total of 25 mice.

\section{RESULTS}

Dirct action of poly $A: U$ on $T$ cells. Both in vivo and in vitro experiments were done. In the former advantage was taken of the finding that poly $A: U$ exerted its effect quickly and was rendered ineffective as an adjuvant in $10 \mathrm{~min}$ by mouse serum (3). Therefore, any direct effect on $\mathrm{T}$ cells alone ought to be revealed by injecting lethally irradiated mice with $T$ cells, SRBC and poly $A: U 1$ day before injection of $\mathrm{B}$ cells and SRBC. Control groups of irradiated mice received $\mathrm{B}$ cells, SRBC and poly $A$ :U 1 day before injection of $T$ cells and SRBC. Within each group spleens were removed 8 days after the last injection of antigen, pooled and assayed for RFC. As may be seen in Table 1, poly A:U enlanced the RFC response approximately 3 fold when injected with $10^{*} \mathrm{~T}$ cells and SRBC 1 day before 13 cells. In contrast little stimulation was achiever of the diminished inmune response in irradiated mice receiving poly $A: U$ and $10^{7} \mathrm{~B}$ cells and antigen 1 clay before $\mathrm{T}$ cells.

TABLE 1

Ix Vivo Amplafication of T Clals By Poty A:U

\begin{tabular}{|c|c|c|c|}
\hline \multirow{2}{*}{ Group $^{a}$} & \multicolumn{2}{|c|}{ Intravenous injection on day } & \multirow{2}{*}{$\frac{\mathrm{RFC} / \text { spleen }}{\text { Day } 10^{d}}$} \\
\hline & 1 & 2 & \\
\hline 1 & $10^{i} \mathrm{~T}$ cells $+\mathrm{SRBC}$ & $10^{7} \mathrm{~B}$ cells $+\mathrm{SRBC}$ & 37,000 \\
\hline 2 & 107 T cells + poly $\mathrm{A}: \mathrm{I}^{\circ}+\mathrm{SRRC}$ & $10^{7} \mathrm{~B}$ cells $+\mathrm{SRBC}$ & 99,000 \\
\hline 3 & $10^{7} \mathrm{~B}$ cells $+\mathrm{SRBC}$ & $10^{7} \mathrm{~T}$ cells $+\mathrm{SRBC}$ & 10,000 \\
\hline 4 & $10^{7} \mathrm{~B}$ cells + poly $\mathrm{A}: \mathrm{U}+\mathrm{SRBC}$ & $10^{7} \mathrm{~T}$ cells $+\mathrm{SRBC}$ & 15,000 \\
\hline 5 & $10^{8} \mathrm{~T}$ cells $+S R B C$ & $10^{7} \mathrm{~B}$ cells $+\mathrm{SRBC}$ & 91,000 \\
\hline 6 & SRBC & $S R B C$ & 0 \\
\hline
\end{tabular}

"Mice received $800 \mathrm{R}$ whole-body irradiation on day 0 .

$" 4 \times 10^{8} \mathrm{SRBC} /$ mouse.

c $600 \mu \mathrm{g}$ poly $\mathrm{A}: \mathrm{U} / \mathrm{mouse}$.

${ }^{d}$ Data represent pooled results of 2 separate experiments with 4-5 mice/group in each. 
A second approach at demonstrating the stimulatory effect of poly $A: U$ directly on thymus-influenced $\mathrm{ARC}$ involved incubating thymic lymphocytes in vitro with antigen and poly $A: U$ for 90 min. After incubation, the $T$ cells were washed 4 times and injected into irradiated mice in graded amounts with $10^{7} \mathrm{~B}$ cells and SRBC. As may been seen in Fig. 1, mice which received SRBC and $5 \times 10^{5}$ thymic lymphocytes that had been incubated with poly $\mathrm{A}: \mathrm{U}$ and $\mathrm{SRBC}$, produced 6-fold more $\mathrm{RFC}$ than mice which received an equivalent number of $\mathrm{T}$ cells incubated with SRBC alone. As in a previous study (1) in which irradiated mice received $\mathrm{T}$ cells and poly $\mathrm{A}: \mathrm{U}$ in vivo, the adjuvant effect of the polynucleotide complex decrcased as the number of thymic lymphocytes injected was increased.

To determine whether poly $A: U$ likewise might stimulate $B$ cells in vitro, the latter were incubated with $S R B C$ and poly $A: U$ in an identical experiment. As may be seen in Table 2, a much lesser stimulatory effect of poly A:U was observed when irradiated mice received $2 \times 10^{6}$ or $1 \times 10^{7} \mathrm{~B}$ cells that had been incubated with poly $A: U$ and SRRC. In contrast the amplifying action of the polynucleotide complex on $\mathrm{T}$ cells was evidenced once again by the control group of irradiated mice which received $10^{6}$ thymic lymphocytes that had been incubated with poly $A: U$ and SRBC. Ten-fold more RFC were seen in these mice.

Nature of the stimulatory effect of poly $A: U$ on thymus-influenced $A R C$. It was not apparent whether poly $\mathrm{A}: \mathrm{U}$ expanded the initial number of $\mathrm{ARC}$ or whether the homoribopolymer complex amplified the activity of each existing ARC which reached the spleen in the above experiments. To differentiate between these two possibilities, the response within each individual mouse spleen was studied. Since

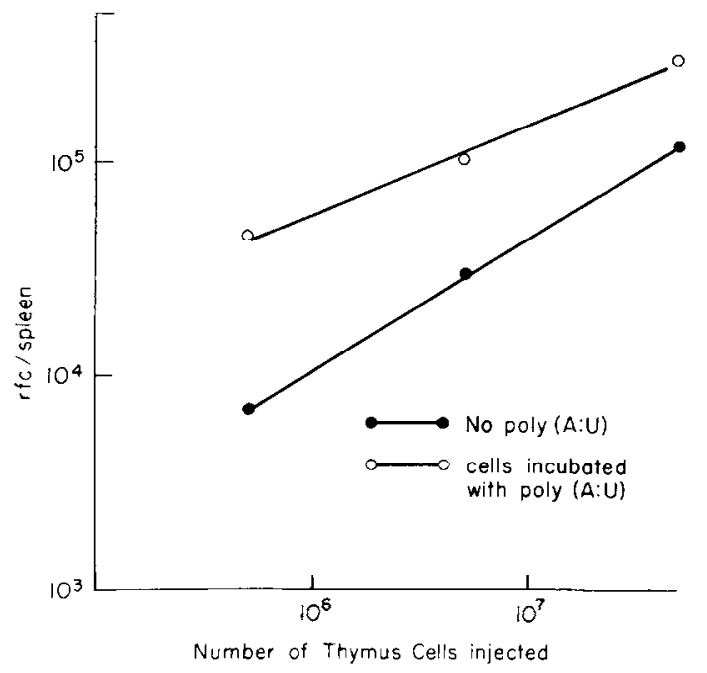

FIG. 1. Restoration of immunocompetence in irradiated mice injected with bone marrow cells and graded numbers of thymus cells incubated in vitro with SRBC \pm poly A:L. Mice receive $800 \mathrm{R}$ whole-body irradiation and 1 day later $1 \times 10^{7}$ bone marrow cells, $4 \times 10^{8}$ SRBC and graded numbers of thymus cells. $5 \times 10^{7} / \mathrm{ml}$ of the latter were incubated in itro with $5 \times 10^{7} / \mathrm{ml} \mathrm{SRBC} \pm$ poly A:U at $150 \mu \mathrm{g} / \mathrm{ml}$. Spleens were removed on day 9, pooled and assayed for RFC. Each point represents the data obtained from a pool of 5-6 spleens. 
the proportion of irradiated mice exhibiting spleens with a positive immune response after receiving excess $B$ cells, antigen and limiting numbers of $T$ cells depends on the number of injected $\mathrm{T}$ cells (6), T lymphocytes were inculated with antigen and poly $\triangle: \mathrm{U}$, and $10^{\circ}$ or $3 \times 10^{\circ}$ cells were injected with SRBC and $10: \mathrm{B}$ cells into irradiated recipients. Splenic RFC were assayed in individual spleens an day 9. Fiffy percent of the mice receiving $10^{6} \mathrm{~T}$ lymphocytes inculated with antigen alone yielded positively responding spleens (as defined in Materials and Methods), while $70 \%$ of the mice receiving $T$ cells that had lseen incubated with SRBC and poly $A: U$ exhibited positive spleens. Thus, poly $A: U$ did not ap pear to increase significantly the number of $\mathrm{ARC}$ reaching the spleen. However, although the number of mice responding was not increased markedly by poly $A: U$ the positively responding spleens from mice receiving $10^{6} \mathrm{~T}$ lymphocytes that had been incubated with poly $A: U$ contained 6 -fold more RFC than positive spleens of mice receiving an exuivalent number of $\mathrm{T}$ cells incubated with antigen alone. These

TABIEE 2

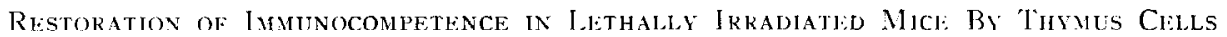
INCEBATED IN VITRO WITH SRBC ANI) P'(), A:L:

\begin{tabular}{|c|c|c|c|}
\hline Group ${ }^{a}$ & Thymus cells injected & Bone marrow cells injected & $\mathrm{RFC} /$ spleen \\
\hline 1 & $4 \times 10^{7}$ & $\begin{array}{c}1 \times 10^{7} \\
\text { (incubated with SRBC) }\end{array}$ & 150,000 \\
\hline 2 & $4 \times 10^{\top}$ & $\begin{array}{c}1 \times 10^{7} \\
\text { (incubated with } \mathrm{SR} B \mathrm{C} \\
\text { and poly } \mathrm{A}: \mathrm{L} \text { ) }\end{array}$ & 220,000 \\
\hline 3 & $4 \times 10^{i}$ & $\begin{array}{c}2 \times 10^{6} \\
\text { (incubated with SRBC) }\end{array}$ & 32,0001 \\
\hline 4 & $4 \times 10^{i}$ & $\begin{array}{l}2 \times 10^{5} \\
\text { (incubated with SRBC } \\
\text { and poly } \mathrm{A}: \mathrm{L}^{-} \text {) }\end{array}$ & 25,000 \\
\hline 5 & $\begin{array}{c}1 \times 10^{6} \\
(\text { incubated with SRBC) }\end{array}$ & $1 \times 10^{7}$ & 5,500 \\
\hline 6 & $\begin{array}{c}1 \times 10^{5} \\
\text { (incubated with } \mathrm{SRBC} \\
\text { and poly } \mathrm{A}: U \text { ) }\end{array}$ & $1 \times 10^{7}$ & 60,000 \\
\hline 7 & $1 \times 10^{6}$ & $\begin{array}{c}1 \times 10^{7} \\
\text { (incubated with } \$ \mathrm{R} B \mathrm{C} \text { ) }\end{array}$ & 8,200 \\
\hline 8 & $1 \times 10^{6}$ & $\begin{array}{c}1 \times 10^{7} \\
\text { (incubated with SRBC } \\
\text { and poly } A: U \text { ) }\end{array}$ & 6,900 \\
\hline 9 & $-\cdots-$ & - & $6,600)$ \\
\hline
\end{tabular}

" Mice received $800 \mathrm{R}$ whole-body irradiation and 24 hr later $4 \times 10^{8} \mathrm{~S} \mathrm{~K} \mathrm{BC}+$ thymus and bone marrow cells IV. Spleens were assayed on day 9 for RFC. Each group represents data obtained from a pool of 5-6 spleens/group. Culture conditions: thymus cells--5 $\times 10^{3} \mathrm{SRBC} / \mathrm{ml} \pm 150$ agms poly A:U/ml; bone marrow cells-1 $\times 10^{7} / \mathrm{ml}+10^{7} \mathrm{SRBC} / \mathrm{ml}+150 \mu \mathrm{gms}$ poly $\mathrm{A}: \mathrm{C} / \mathrm{ml}$. 
results suggested that poly $A: U$ amplified the activity of those $A R C$ which reached the spleen.

To examine further the nature of this amplifying effect, a double transfer experiment similar to that used by Mitchell and Miller (7) was employed. In this type of experiment it was shown that $\mathrm{T}$ cells injected into an irradiated mouse (primary host) will seed the spleen and proliferate in response to antigenic challenge (8). The activity of these cells may then be assessed by transferring spleen cells from the primary host along with antigen and fresh $B$ cells to a second irradiated mouse (secondary host). Since the number of RFC produced in irradiated mice receiving SRBC, an excess number of $B$ cells and graded numbers of $T$ cclls, was proportional to the number of thymus cells injected (1), any increase in RFC in the spleens of secondary hosts, receiving primary host spleen cells removed at various times after injection of $T$ cells and antigen, should be a reflection of the increase in thymus influenced ARC in the spleens of primary hosts. Accordingly, such a double transfer experiment was used to determine what effect poly $A: U$ had on the proliferative rate of $\mathrm{ARC}$ responding to antigenic challenge.

Lethally irradiated mice (primary hosts) received $2 \times 10^{7} \mathrm{~T}$ lymphocytes, $\mathrm{SRBC}$ and poly $\mathrm{A}: \mathrm{U}$. Their spleens were removed 24,48 and $72 \mathrm{hr}$ after injection, the cells dispersed, pooled and $10^{7}$ spleen cells were injected with $10^{7} \mathrm{~B}$ cells and SRBC into a second group of lethally irradiated mice (secondary hosts). Eight days after the secondary hosts received primary host cells, B cells and antigen, the spleens of secondary host mice were removed and assayed individually for RFC. No immune response was detected in secondary hosts injected with SRBC, $B$ cells and spleen cells obtained from primary hosts injected with SRBC alone, indicating that no $\mathrm{ARC}$ were present in the irradiated primary host. As may be seen in Fig. 2 injection of SRBC, B cells and spleen cells obtained from primary hosts $24 \mathrm{hr}$ after injection of SRBC and T cells, enabled $20 \%$ of the secondary hosts to respond to antigenic challenge. This number of $A R C$ in the spleens of primary hosts receiving $\mathrm{T}$ cells and SRBC increased between 24 and $48 \mathrm{hr}$ as evidenced by the finding that $80 \%$ of the mice yielded positive spleens when receiving primary host spleen cells removed $48 \mathrm{hr}$ aftcr injection of SRBC and T cells. That the $\mathrm{T}$ cells were proliferating in response to antigenic challenge was indicated by the observation that there was little increase in the proportion of secondary hosts receiving spleen cells removed from primary hosts 24 or $48 \mathrm{hr}$ after injection of $\mathrm{T}$ cells without antigen. Sixty percent of the secondary hosts receiving SRBC, B cells and spleen cells obtained from primary hosts $24 \mathrm{hr}$ after injection of SRBC, T cells and poly $\mathrm{A}: \mathrm{U}$ responded to antigenic challenge, indicating a greater number $(60 \%$ vs 20\%) of $\mathrm{ARC}$ in the spleens of primary hosts receiving poly $\mathrm{A}: \mathrm{U}$. This number of $\mathrm{ARC}$ in primary hosts receiving poly $\mathrm{A}: \mathrm{U}$ also increased between 24 and 48 hr after injection such that spleen cells removed from poly $A: L$-treated primary hosts $48 \mathrm{hr}$ after injection enabled $100 \%$ of the secondary hosts to respond to antigenic challenge. That the polynucleotide complex had amplified the activity of $\mathrm{ARC}$ in primary hosts was also indicated by the observation that spleen cells removed from poly $A$ :U treated primary hosts enabled the production of 2 to 6 fold more $\mathrm{RFC}$ /positive spleen than spleen cells obtained from primary hosts receiving SRBC and $\mathrm{T}$ cells alone. Furthermore, the number of $\mathrm{RFC} /$ positive spleen in secondary 


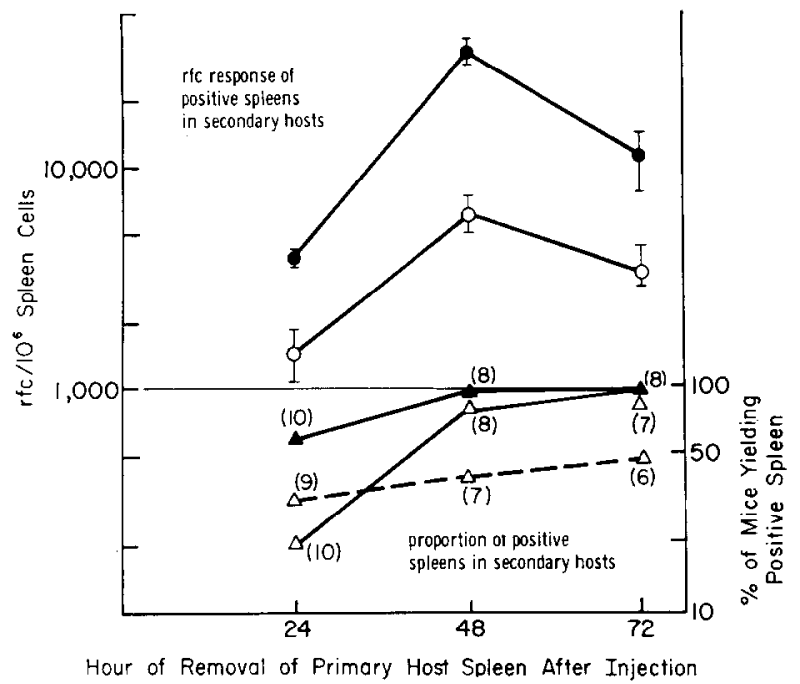

FIG. 2. RFC formation in irradiated secondary host mice injected with SRBC, bone marrow cells and spleen cells removed from irradiated primary host mice. Irradiated mice $(800 \mathrm{R})$ received $4 \times 10^{8} \mathrm{SRBC}, 1 \times 10^{7}$ bone marrow cells and $1 \times 10^{7}$ spleen cells obtained from irradiated mice 24,48 , or $72 \mathrm{hr}$ after IV injection of $2 \times 10^{7}$ thymus cells, $4 \times 10^{8}$ $\mathrm{SRBC} \pm 600 \mu \mathrm{g}$ poly $\mathrm{A}: \mathrm{U}$. Spleens of secondary hosts were removed 8 days after injection of antigen and assayed individually for RFC. Each point represents the pooled results of 2 separate experiments. Vertical bars denote $1 \mathrm{SE}$ of arithmetic mean. $-22^{\circ}$ host receiving SRBC, Bune Marrow Cells and Spleen Cells from $\mathbf{A}-\mathbf{\Delta} 1^{\circ}$ host injected with SRBC, Poly A :U and Thymus Cells. $\bigcirc-O 2^{\circ}$ host receiving SRBC, Bone Marrow Cells and Spleen Cells from $\triangle \longrightarrow \triangle 1^{\circ}$ host injected with SRBC and Thymus Cells. $\triangle---\triangle 2^{\circ}$ recciving SRBC, Bonc Marrow Cells and Splecn Cells from $1^{\circ}$ host injected with Thymus Cells.

hosts receiving spleen cells removed from primary hosts $48 \mathrm{hr}$ after injection of antigen and $\mathrm{T}$ cells was 4-fold higher than the number of RFC induced by spleen cells removed $24 \mathrm{hr}$ after injection. Primary host splecn cells removed $48 \mathrm{hr}$ after injection of SRBC, $T$ cells and poly $A: U$ induced 10 fold more RFC than spleen cells removed from poly $\mathrm{A}$ :U-treated primary hosts removed at $24 \mathrm{hr}$. If the increase in $\mathrm{RFC}$ is an accurate reflection of the increase in ARC, the number of ARC in poly $A: U$ treated primary hosts doubled in approximately $7 \mathrm{hr}$, while ARC in primary hosts injected with $T$ cells and antigen alone doubled in $12 \mathrm{hr}$.

Thus, the results suggested that poly $\mathrm{A}: \mathrm{U}$ increased the rate of proliferation of $\mathrm{ARC}$ in response to antigenic challenge. In addition, the increased number of $\mathrm{ARC}$ in the spleens of irradiated mice within $24 \mathrm{hr}$ after injection of T cells, SRBC and poly $A: U$ indicated that antigen-stimulated division of ARC may have begun earlier in poly $A: U$-treated animals.

Amplification of $\mathrm{ARC}$ by poly $\mathrm{A}: \mathrm{U}$, as demonstrated in the irradiated-reconstituted mouse model, might also explain the restoration by poly $\mathrm{A}: \mathrm{U}$ of immunocompetence in neonatally thymectomized (NTx) mice (1). To test this hypothesis, the rate of increase in antibody producing cells was determined as well as the time at which the immune response of poly A:U-treated NTx mice became susceptible to 
the inlibitory effects of vinblastine (VLB). Thus, five week old NTx mice received $S R B C \pm$ poly $A: L$ or $T$ lymphocytes. Spleens were removed at various times after injection of antigen and assayed for RFC. As may be seen in Fig. 3, the number of splenic RFC in NTx mice receiving antigen alone doubled in $24 \mathrm{hr}$ and there was little further increase in $\mathrm{RFC}$ after day 3 . When $\mathrm{N} T \mathrm{x}$ mice received SRBC and poly $\mathrm{A}: \mathrm{U}$ or thymic lymphocytes, splenic RFC increased exponentially to day 4 with a doubling time of $18 \mathrm{hr}$. The number of RFC in NTX mice receiving poly $A: U$ and SRBC increased further between days 4 and 6 while the increase was not extended in unoperated mice or $\mathrm{NTx}$ mice receiving antigen and thymic lymphocytes. Thus, the rate of increase of antibody forming cells in NTx mice was enhanced by poly $A: U$.

The possibility that the homoribopolymer complex stimulated earlier initiation of division of immunocompetent cells was examined with the use of a mitotic inhibitor, vinblastine. Since dividing cells are inhibited by $\operatorname{VLB}(9,10)$, this drug has been used to determine when immunocompetent cells began to divide after injection of antigen $(8,11)$. Prior to determining the effect of poly $A: U$ in VLB-treated NTx mice, the effect of the polynucleotide complex was studied in VLB-treated, unoperated animals. Five week old, unoperated mice received intravenously, SRBC and poly $A: U$ and 6,12 or $24 \mathrm{hr}$ later $0.05 \mathrm{mg}$ VLB intraperitoneally. Spleens were removed 3 days after injection of antigen and assayed for RFC. As may be seen in Fig. 4, VLB suppressed the immune response of mice receiving antigen alone when injected $12 \mathrm{hr}$ or more after injection of antigen. In contrast, 93\% suppression of the immune response was achieved when VLB was injected $6 \mathrm{hr}$

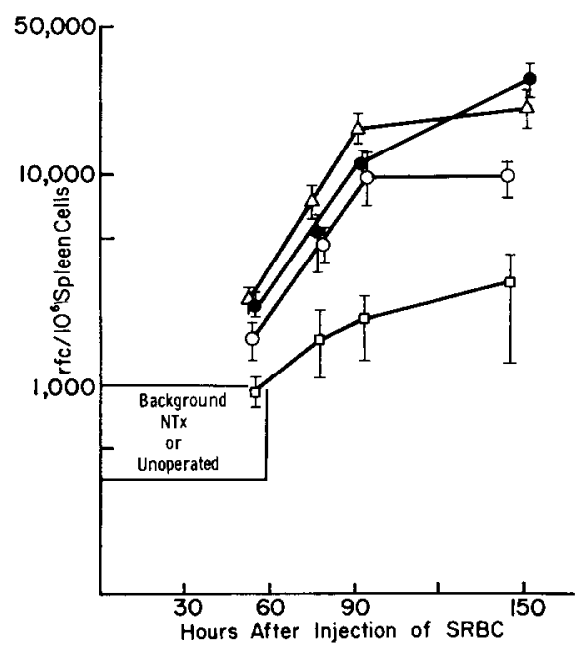

FIG. 3. Kinetics of splenic RFC response to SRBC in NTx and unoperated mice. Mice were injected intravenously with $4 \times 10^{8} \mathrm{SRBC}$ either alone or with $5 \times 10^{-}$thymic lymphocytes or $600 \mu \mathrm{g}$ poly $\mathrm{A}: \mathrm{U}$. Spleens were removed at designated intervals after injection of antigen and assayed for RFC. Each point represents the arithmetic mean of data obtained from 4-5 mice/group. Vertical bar represents $1 \mathrm{SE}$ of arithmetic mean. $\square-\square \mathrm{NTx}$ mice injected with SRBC. $O-O N T x$ mice injected with SRBC + thymus cells. - NTx mice injected with SRBC + poly A:U. $\triangle \longrightarrow \triangle$ Unoperated mice injected with SRBC. 


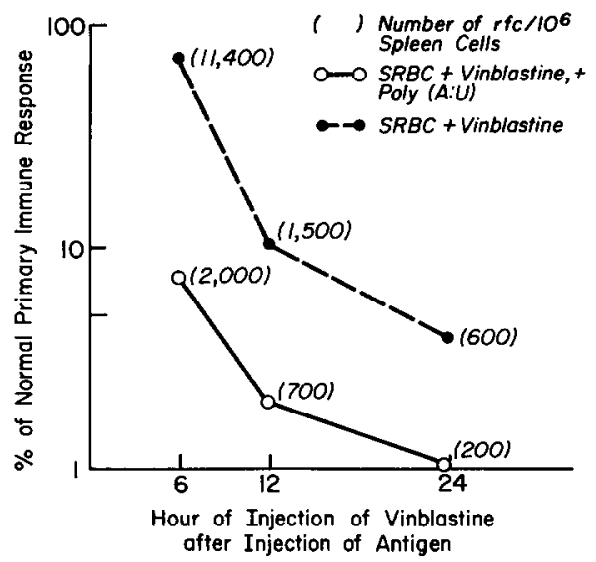

FIG. 4. Early effect of vinblastine on the immune response of mice injected with SRBC and poly $A: U$. Mice were injected intravenously with $4 \times 10^{8}$ SRBC $+600 \mu \mathrm{g}$ poly $A: U$ and intraperitoneally with $0.05 \mathrm{mg}$ vinblastine 6,12 , or $24 \mathrm{hr}$ later. Spleens were removed on day 3, pooled and assayed for RFC. Each point represents data obtained from 3-4 mice/group.

after injection of SRBC and poly A:U. Similarly, as may be seen in Table 3, VLB suppressed the immune response of NTx mice when injected $12 \mathrm{hr}$ or more after injection of SRBC. When NTx mice received SRBC and poly A:U, VLB inhibited the immune response when given with, or $6 \mathrm{hr}$ or more after, injection of antigen. These results suggested that antigen induced proliferation of immunocompetent cells began at least $6 \mathrm{hr}$ earlier in poly A :U treated NTx or unoperated animals.

\section{DISCUSSION}

A direct, stimulatory effect of poly $A: U$ on thymus-influenced $A R C$ was demonstrated by the finding that incubation of thymus cells with SRBC and poly $A: U$

TABLE 3

Effect of Vinblastine on Poly A:U-Induced Restoration OF IMMUNOCOMPETENCE OF NTX MicF

\begin{tabular}{|c|c|c|c|c|}
\hline \multirow[b]{2}{*}{ Inoculum ${ }^{a}$} & \multicolumn{2}{|c|}{ Poly A:U-treated NTx mice } & \multicolumn{2}{|c|}{ Untreated NTx mice } \\
\hline & $\begin{array}{c}\mathrm{RFC} / 10^{6} \\
\text { spleen cells }\end{array}$ & $\%$ reduction & $\begin{array}{l}\mathrm{RFC} / 10^{\circ} \\
\text { spleen cells }\end{array}$ & $\%$ reduction \\
\hline $\mathrm{SRBC}$ & 4,500 & - & 1,400 & - \\
\hline$S R B C+V L B$ & & & & \\
\hline $0 \mathrm{hr}$ & 680 & 85 & 1,500 & 0 \\
\hline $6 \mathrm{hr}$ & 650 & 86 & 1,500 & 0 \\
\hline $12 \mathrm{hr}$ & 440 & 90 & 430 & 65 \\
\hline $24 \mathrm{hr}$ & 620 & 88 & 260 & 89 \\
\hline
\end{tabular}

${ }^{a} \mathrm{NTx}$ mice received $4 \times 10^{8} \mathrm{SRBC} \pm 000 \mu \mathrm{g}$ poly $\mathrm{A}: \mathrm{U}$ IV and $0.05 \mathrm{mg}$ vinblastine IP 0.6 , 12 or $24 \mathrm{hr}$ after injection of antigen. Spleens were removed on day 3 and assayed for RFC. Each group represents the data obtained from a pool of $3-5$ spleens. VI.B $=$ vinblastine sulfate. 
in rivo ancl in rivo prior to injection of $\mathrm{B}$ cells enhanced the anti-SRBC response of irradiated mice. In contrast, the inability of the homoribopolymer complex to stimulate $\mathrm{B}$ cells in vivo or in vitro indicated that poly $\mathrm{A}: \mathrm{U}$ does not exert directly, an adjuvant effect on AFPC of bone marrow origin. The observation that no adjuvant effect was achieved when irradiated mice received $10^{\circ}$ thymic lymphocytes. SRIBC and $10^{7} \mathrm{~B}$ cells with only the latter exposed to poly $A: U$ suggested further that the inability to demonstrate an adjuvant effect on $B$ cells was not due to masking of the effect by injection of large numbers of $T$ cells.

The magnitude of the increase in frequency of positively responding mice injected with antigen, excess $B$ cells and limiting numbers of poly $A: U$-treated $T$ cells was too small to account for the increased number of antibody forming cells in the spleens of responding mice. Thus, the major effect of poly $A: U$ would appear to be to amplify the activity of those ARC which have reached the spleen of the irradiated animal. The finding that injection of poly $A: U$ with SRBC did not increase significantly the number of anti-SRBC hemolytic foci/spleen in normal animals, but rather increased the number of plaque forming cells/foci (12) is in agreement with this hypothesis. The amplification of $A R C$ by poly $A: U$ might be brouglit about in several ways: (a) increased rate of proliferation of $A R C$, resulting in increased numbers and rate of activation of AFPC, (b) increased numbers of divisions of ARC, (c) increased efficiency of individual ARC such that an individual ARC night interact with a larger number of AFPC.

The data obtained from double transfer experiments suggested that poly $A: U$ enlanced the rate of increase of $\mathrm{ARC}$ in response to antigenic challenge. The theoretical doubling time of $\mathrm{ARC}$ calculated from data obtained in double transfer experiments is in agreement with that olstained by others (8). Treatment of irradiated primary hosts with poly $\mathrm{A}: \mathrm{U}$ resulted in a shortening of the cloubling time of $\triangle R C$ by 5 hr. Similarly, the doubling time of RFC in NTx mice treated with poly $A: L$ was decreased by $6 \mathrm{hr}$. The results suggested that at least one of the factors affecting the rate of proliferation of antibody forming cells may be the proliferative rate of $A R C$. In support of this concept, the rate of recruitment of antibody forming cells was found to proceed exponentially (11). Thus, the increased proliferative rate of $\mathrm{RFC}$ in poly $\mathrm{A}: \mathrm{U}$-treated NTx mice might be a reflection of an increase in the rate of proliferation of $\mathrm{ARC}$. The susceptibility of mice receiving poly $A: U$ and antigen to the immunosuppressive effects of VLB within 6 hr after injection of antigen suggested that the homoribopolymer complex also induced an earlier proliferation of immunocompetent cells in response to antigenic challenge. Since the antigen-induced expansion of $\triangle R C$ may be inhibited by VLB (8), it is probable that poly $\backslash: \mathrm{U}$ stimulated even earlier divisions of ARC. These data offer a likely explanation for the early appearance of antibody in the blood stream of poly $\mathrm{A}: \mathrm{U}$ treated animals $(3)$.

The nature of the interactions between ARC and antigen and/or AFPC is unknown. The ability of poly $A: U$ to amplify the activity of $\mathrm{ARC}$ suggests that the homoribopolymer complex might be a useful tool in defining the precise role these cells play during the immune response. In addition, the ability of the homoribopolymer complex "to restore" immunocompetence to animals rendered deficient in thymus-influenced cells holds promise as a means of therapy for individuals suffer- 
ing from immunologic deficiency syndromes in which the thymus is not absent but is poorly developed (13).

\section{ACKNOWLEDGMENT}

The authors gratefully acknowledge the expert advice and help of Dr. Toni Mariani, University of Minnesota, in the technique of thymectomy.

\section{REFERENCES}

1. Cone, R. E., and Johnson, A. G., J. Exp. Med. 133, 665, 1971.

2. Braun, W., and Nakano, M., Scicnce 157, 819, 1967.

3. Schmidtke, J. R., and Johnson, A. G., J. Immunol. 106, 1191, 1971.

4. Murphy, W. H., and Syverton, J. T., Cancer Res. 21, 921, 1961.

5. Sjodin, L., Dalmasso, A. P., Smith, J. M., and Martinez, C., Transplantation 1, 521, 1963.

6. Shearer, G. M., Cudkowicz, G., and Priore, R. L., J. Ext. Med. 130, 481, 1969.

7. Mitchell, G. F., and Miller, J. F. A. P., Proc Nat. Acad. Sci. (USA) 59, 296, 1968.

8. Shearer, G. M., and Cudkowicz, G., J. Exp. Med. 130, 124, 1969.

9. Bruchoysky, N., Owen, A. A., Becker, A. J., and Till, J. E., Cancer Res. 25, 1232, 1965.

10. Palmer, C. G., Livengood, P., Warren, A. K., Simpson, P. J., and Johnson, I. S., Exp. Cell K'es. 20, 198, 1960.

11. Perkins, E. H., Sado, T., and Makinodan, T., J. Immunol. 103, 668, 1969.

12. Braun, W., Nakano, M., Jaraskova, L., Yagima, Y., and Jimenez, L., "Nucleic Acids in Immunology." (O. J. Plescia and W. Braun, eds.), Springer-Verlag, NY, 1968.

13. Hess, M. W., "Experimental Thymectomy." Possibilities and Limitations. Springer-Verlag, NY, 1968. 